\begin{tabular}{|c|c|c|c|c|c|c|}
\hline \multirow{4}{*}{ Impact Factor: } & ISRA (India) & $=3.117$ & SIS (USA) & $=0.912$ & ICV (Poland) & $=6.630$ \\
\hline & ISI (Dubai, UAE & $=0.829$ & РИНЦ (Russia & $=0.156$ & PIF (India) & $=1.940$ \\
\hline & GIF (Australia) & $=0.564$ & ESJI (KZ) & $=8.716$ & IBI (India) & $=4.260$ \\
\hline & JIF & $=1.500$ & SJIF (Morocco & $=5.667$ & OAJI (USA) & $=0.350$ \\
\hline
\end{tabular}

\section{SOI: $\underline{1.1 / T A S}$ DOI: $\underline{10.15863 / T A S}$ \\ International Scientific Journal Theoretical \& Applied Science}

p-ISSN: 2308-4944 (print) e-ISSN: 2409-0085 (online)

Year: 2019 Issue: 03 Volume: 71

Published: $30.03 .2019 \quad \underline{\text { http://T-Science.org }}$

SECTION 31. Economic research, finance, innovation, risk management.
QR - Issue

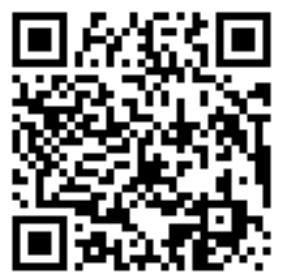

Muqaddas Abbasovna Umarova

Doctorate, Candidate of economics, associate professor, Tashkent state university of economics, Tashkent city, Republic of Uzbekistan

\title{
STATISTICAL EVALUATION OF LABOR FORCE STRUCTURE (IN THE CASE OF UZBEKISTAN)
}

Abstract: The article analyzes the structure of the labor force of the Republic of Uzbekistan. Based on the secondary statistical data, the author conducted an empirical study and identified the main factors. At the end of the article, a forecast of employment for the population until 2022 has been proposed.

Key words: population, employment, labor, labor resources, statistics.

Language: English

Citation: Umarova, M. A. (2019). Statistical evaluation of labor force structure (in the case of Uzbekistan). ISJ Theoretical \& Applied Science, 03 (71), 553-563.

Soi: http://s-o-i.org/1.1/TAS-03-71-55 Doi: crossef https://dx.doi.org/10.15863/TAS.2019.03.71.55

\section{Introduction}

The role of statistical forecasting in building a balanced composition and predictability of the labor market in any country is unmatched. However, the direct use of statistical forecasting in the labor market can lead to inaccurate conclusions and its methodological aspects need to be improved.

In Uzbekistan, one of the countries with rich labor resources, this issue has risen to a level of public policy. In 2017-2021, a strategy for the development of the Republic of Uzbekistan in five priority areas of the Republic of Uzbekistan was developed in the "Year of Active Investments and Social Development" - a state program to be implemented in 2019.

In the market economy, business entities seek to make production programs using as fewer workforce as possible. As a result, in all sectors, it will try to get rid of excess labor. This, in turn, raises questions of employment, redistribution and recruitment. In addition, the natural increase in the high labor force in the labor market also exacerbates pressure. The part of the labor force, which enters the labor market, is more than 400 thousand people a year, which could lead to the disruption of the labor force demand and the unemployment rate among young people.

\section{Literature review}

Based on this, statistical forecasting is crucial in terms of ensuring that future employment and human resources will not increase.
Studying scientific literature and world experience shows that the transition to a market economy, including the labor market, is very complex, and this is a matter of other processes taking place in the transition from one system to another.

The labor market and the employment of the population are a complex socio-economic issue, and many have been the subject of economic statistics research.

The theoretical and methodological aspects of addressing the problems related to the employment of the population and the labor market are promoted by well-known academics of foreign and CIS countries, including J. M. Kains [6], R.E.Lukas [7], A.Osvald [8], X. Rozan [9], J.Rudebsh [10], F.Hayek [11], T.I.Zaslavskaya [12], V.Kostakov [13], A.Kotlyar [14]. It was investigated by Maslova [15], A.A.Nikifirova [16], S.G.Strumilin [17] and others.

Theoretical and practical aspects of the employment of the population and the labor market in the Republic are given by economist $\mathrm{K}$. Kh.Abdurahmonov [18], N.Allikiev [19], L.M.Maksakova [20], Sh.Yu.Maxkamova [21] , A.Tashpulatov [22], R.AUbaydullaeva [23] Sh.R. Kholmuminov, N.Khodjaev, T.Sh.Shodiev [23], Ibragimov I.[24-25], Tursunov B. [26], Kasymov S. [27] and others. They explored the issues of the formation and development of the labor market, the issues of unemployment, labor force social protection, employment of certain social and demographic groups and creation of new jobs. 


\begin{tabular}{|c|c|c|c|c|c|c|}
\hline \multirow{4}{*}{ Impact Factor: } & ISRA (India) & $=\mathbf{3 . 1 1 7}$ & SIS (USA) & $=0.912$ & ICV (Poland) & $=6.630$ \\
\hline & ISI (Dubai, UAE & $=0.829$ & РИНЦ (Russia & $=0.156$ & PIF (India) & $=1.940$ \\
\hline & GIF (Australia) & $=0.564$ & ESJI (KZ) & $=8.716$ & IBI (India) & $=4.260$ \\
\hline & JIF & $=1.500$ & SJIF (Morocce & $=5.667$ & OAJI (USA) & $=0.350$ \\
\hline
\end{tabular}

\section{Methods}

In the article, statistical analysis, correlationship, regression analysis and comparisons were used. was based on the secondary data of the State Statistical Committee of the Republic of Uzbekistan and the Ministry of Labor and Employment of the Republic of Uzbekistan.

\section{Analysis and results}

In the Republic of Uzbekistan, the labor market began to emerge after its radical independence. The Oliy Majlis has adopted the laws "On employment of the population" (January 13, 1992, 510-XII) [1] and "On employment of the population".

As a result, nowadays various forms of labor activity, new forms and methods of entrepreneurship have emerged. Entrepreneurial layers of the population, actively engaged in market relations, have emerged. In recent years, more and more NGOs have been focusing on the employment of the population. The general strategy for the transition to a market economy developed in our country has been reflected in several accepted normative and legal acts. The Decree of the President of the Republic of Uzbekistan
"On Further Deepening Economic Reforms, Protection of Private Property and Entrepreneurship" of 21 January 1994 was a major impetus for the transition to market economy [3]. As a result, major changes in the labor market have taken place and the transition to the second phase of transition to market economy has taken place.

In pursuance of the Decree of the President of the Republic of Uzbekistan from July 14, 2018 "On measures to improve and increase the effectiveness of employment of the population" PQ-3856, of June 8, 2018 "Every family entrepreneur" Implementation of the Law "On Improvement of the Labor Market Activity" [5].

Table 1 shows that in recent years, the employment rate of the population with absolute and relative employment has been rising [28]. In 1991, the number of people employed in various sectors of the economy was 8254.6 thousand people, in $1996-8$ 561.0 thousand people, in $2017-13520.3$ thousand people. That is, the number of employed people in 2017 increased by $5,265.7$ thousand people or $63.8 \%$ compared to 1991. The average annual growth rate of the employed population was 1.9 percent per year (Table 1).

Table 1. Dynamics of employment in the Republic of Uzbekistan during the years of independence

\begin{tabular}{|c|c|c|c|c|c|c|c|c|}
\hline \multirow{2}{*}{ Years } & \multirow{2}{*}{$\begin{array}{l}\text { Average } \\
\text { number of } \\
\text { employed } \\
\text { people per } \\
\text { year, } \\
\text { thousand } \\
\text { people }\end{array}$} & \multicolumn{2}{|c|}{$\begin{array}{l}\text { Absolute additional } \\
\text { increase (decrease), } \\
\text { thousand people }\end{array}$} & \multicolumn{2}{|c|}{ Growth rate, $\%$} & \multicolumn{2}{|c|}{$\begin{array}{c}\text { Increase (decrease) } \\
\text { rate, } \%\end{array}$} & \multirow{2}{*}{$\begin{array}{l}1 \% \text { absolute } \\
\text { value of } \\
\text { additional } \\
\text { growth } \\
\text { (reduction), } \\
\text { thousand } \\
\text { people }\end{array}$} \\
\hline & & Chain & base & Chain & base & Chain & base & \\
\hline 1 & 2 & 3 & 4 & 5 & 6 & 7 & 8 & 9 \\
\hline 1991 & 8254,6 & & & & 100,0 & & & \\
\hline 1992 & 8271,0 & 16,4 & 16,4 & 100,2 & 100,2 & 0,2 & 0,2 & 82,5 \\
\hline 1993 & 8259,0 & $-12,0$ & 4,4 & 99,9 & 100,1 & $-0,1$ & 0,1 & 82,7 \\
\hline 1994 & 8379,0 & 120,0 & 124,4 & 101,5 & 101,5 & 1,5 & 1,5 & 82,6 \\
\hline 1995 & 8449,2 & 70,2 & 194,6 & 100,8 & 102,4 & 0,8 & 2,4 & 83,8 \\
\hline 1996 & 8561,0 & 111,8 & 306,4 & 101,3 & 103,7 & 1,3 & 3,7 & 84,5 \\
\hline 1997 & 8680,0 & 119,0 & 425,4 & 101,4 & 105,2 & 1,4 & 5,2 & 85,6 \\
\hline 1998 & 8800,0 & 120,0 & 545,4 & 101,4 & 106,6 & 1,4 & 6,6 & 86,8 \\
\hline 1999 & 8885,0 & 85,0 & 630,4 & 101,0 & 107,6 & 1,0 & 7,6 & 88,0 \\
\hline 2000 & 8983,0 & 98,0 & 728,4 & 101,1 & 108,8 & 1,1 & 8,8 & 88,9 \\
\hline 2001 & 9136,0 & 153,0 & 881,4 & 101,7 & 110,7 & 1,7 & 10,7 & 89,8 \\
\hline 2002 & 9333,0 & 197,0 & 1078,4 & 102,2 & 113,1 & 2,2 & 13,1 & 91,4 \\
\hline 2003 & 9589,0 & 256,0 & 1334,4 & 102,7 & 116,2 & 2,7 & 16,2 & 93,3 \\
\hline 2004 & 9910,6 & 321,6 & 1656,0 & 103,4 & 120,1 & 3,4 & 20,1 & 95,9 \\
\hline 2005 & 10196,3 & 285,7 & 1941,7 & 102,9 & 123,5 & 2,9 & 23,5 & 99,1 \\
\hline 2006 & 10467,0 & 270,7 & 2212,4 & 102,7 & 126,8 & 2,7 & 26,8 & 102,0 \\
\hline 2007 & 10735,4 & 268,4 & 2480,8 & 102,6 & 130,1 & 2,6 & 30,1 & 104,7 \\
\hline 2008 & 11035,4 & 300,0 & 2780,8 & 102,8 & 133,7 & 2,8 & 33,7 & 107,4 \\
\hline 2009 & 11328,1 & 292,7 & 3073,5 & 102,7 & 137,2 & 2,7 & 37,2 & 110,3 \\
\hline 2010 & 11628,4 & 300,3 & 3373,8 & 102,6 & 140,9 & 2,6 & 40,9 & 113,3 \\
\hline 2011 & 11919,1 & 290,7 & 3664,5 & 102,5 & 144,4 & 2,5 & 44,4 & 116,3 \\
\hline
\end{tabular}




\begin{tabular}{|c|c|c|c|c|c|c|}
\hline \multirow{4}{*}{ Impact Factor: } & ISRA (India) & $=\mathbf{3 . 1 1 7}$ & SIS (USA) & $=0.912$ & ICV (Poland) & $=6.630$ \\
\hline & ISI (Dubai, UAE & $=0.829$ & РИНЦ (Russia & $=0.156$ & PIF (India) & $=1.940$ \\
\hline & GIF (Australia) & $=0.564$ & ESJI (KZ) & $=8.716$ & IBI (India) & $=4.260$ \\
\hline & JIF & $=1.500$ & SJIF (Morocco & $=5.667$ & OAJI (USA) & $=0.350$ \\
\hline
\end{tabular}

\begin{tabular}{|c|c|c|c|c|c|c|c|c|}
\hline 2012 & 12223,8 & 304,7 & 3969,2 & 102,6 & 148,1 & 2,6 & 48,1 & 119,2 \\
\hline 2013 & 12523,3 & 299,5 & 4268,7 & 102,5 & 151,7 & 2,5 & 51,7 & 122,2 \\
\hline 2014 & 12818,4 & 295,1 & 4563,8 & 102,4 & 155,3 & 2,4 & 55,3 & 125,2 \\
\hline 2015 & 13058,3 & 239,9 & 4803,7 & 101,9 & 158,2 & 1,9 & 58,2 & 128,2 \\
\hline 2016 & 13298,4 & 240,1 & 5043,8 & 101,8 & 161,1 & 1,8 & 61,1 & 130,6 \\
\hline 2017 & 13520,3 & 221,9 & 5265,7 & 101,7 & 163,8 & 1,7 & 63,8 & 133,0 \\
\hline Mean & $\mathbf{9 8 8 5 , 7}$ & $\mathbf{2 0 2 , 5}$ & & $\mathbf{1 0 1 , 9}$ & & $\mathbf{1 , 9}$ & & \\
\hline
\end{tabular}

Source: author's calculations based on statistical data of the state statistics committee of the republic of Uzbekistan

However, in our opinion, some factors have a negative impact on the efficiency of these processes. For example, in rural areas, the density and excessive labor force in the social infrastructure sector is insufficient.

At the moment, the labor market is complex, with its new principles and mechanisms of market economy, there are hidden and semi-confidential cases that have a negative impact on market economy elements inherited from previous years.

The open labor market includes a relatively small portion of the economically active population, mostly educated by highly qualified educated people.

In 2017, the number of labor resources was $18,666.3$ thousand (57.6 percent of the total population) and the economically active population was $14,357.3$ thousand people, of which 94.8 percent or 13298.4 thousand people were employed in the economy busy

In 2010, there were some changes in the number of employed people in comparison with 2017 (Table 2 ). In particular, the share of those employed in agriculture and forestry increased from $26.8 \%$ in 2000 to $27.3 \%$ in 2017 , while the share of employed in the industry decreased from $13.8 \%$ to $13.5 \%$, respectively. There was an increase in the shares in all other sectors.

Table 2. Those who are employed in the labor market of Uzbekistan sectoral distribution in 2010-2017

\begin{tabular}{|l|c|c|c|c|}
\hline \multirow{2}{*}{1} & \multicolumn{2}{|c|}{ Thousands } & \multicolumn{2}{c|}{ In\% of total } \\
\cline { 2 - 5 } & $\mathbf{2 0 1 0} \mathbf{~ y .}$ & $\mathbf{2 0 1 7} \mathbf{~ y .}$ & $\mathbf{2 0 1 0} \mathbf{~ y .}$ & $\mathbf{2 0 1 7} \mathbf{~ y . ~}$ \\
\hline \multicolumn{1}{|c|}{ Total } & 2 & 3 & 4 & 5 \\
\hline \multicolumn{1}{|c|}{ including: } & $\mathbf{1 1 6 2 8 , 4}$ & $\mathbf{1 3 5 2 0 , 3}$ & $\mathbf{1 0 0 , 0}$ & $\mathbf{1 0 0 , 0}$ \\
\hline agriculture, forestry and fishery & 3118,1 & 3686,5 & 26,8 & 27,3 \\
\hline Industry & 1605,7 & 1825,2 & 13,8 & 13,5 \\
\hline Construction & 1033,7 & 1290,0 & 8,9 & 9,5 \\
\hline Sales & 1235,6 & 1480,4 & 10,6 & 11,0 \\
\hline transportation and storage & 509,9 & 655,0 & 4,4 & 4,8 \\
\hline living and dietetic services & 249,2 & 313,3 & 2,1 & 2,3 \\
\hline information and communication & 53,1 & 64,3 & 0,5 & 0,5 \\
\hline financial and insurance activities & 69,9 & 68,1 & 0,6 & 0,5 \\
\hline Education & 1102,0 & 1106,4 & 9,5 & 8,2 \\
\hline $\begin{array}{l}\text { health and social services } \\
\text { art, leisure and entertainment } \\
\text { other types of services }\end{array}$ & 596,2 & 602,4 & 5,1 & 4,5 \\
& 64,4 & 65,4 & 0,6 & 0,5 \\
& 1990,6 & 2363,3 & 17,1 & 17,4 \\
\hline
\end{tabular}

Source: author's calculations based on statistical data of the state statistics committee of the republic of Uzbekistan 


\begin{tabular}{|c|c|c|c|c|c|c|}
\hline \multirow{4}{*}{ Impact Factor: } & ISRA (India) & $=\mathbf{3 . 1 1 7}$ & SIS (USA) & $=0.912$ & ICV (Poland) & $=6.630$ \\
\hline & ISI (Dubai, UAE & $=0.829$ & РИНЦ (Russia & $=0.156$ & PIF (India) & $=1.940$ \\
\hline & GIF (Australia) & $=0.564$ & ESJI (KZ) & $=8.716$ & IBI (India) & $=4.260$ \\
\hline & JIF & $=1.500$ & SJIF (Morocco & $=5.667$ & OAJI (USA) & $=0.350$ \\
\hline
\end{tabular}

There are also changes in the distribution of employed persons by type of ownership; in 2010, $20.7 \%$ of total employment was in state-owned enterprises and organizations, while in 2017 this share declined by $17.3 \%$. In $2010,11,182.0$ thousand people were employed in the non-state sector, from $9,218.2$ thousand persons, or $78.0 \%$ were representatives of private entrepreneurs and small businesses (Table 3).

Table 3. Distribution of employed in the labor market of the Republic of Uzbekistan for 2010-2017 by type of ownership

\begin{tabular}{|c|c|c|c|c|c|c|}
\hline \multirow[b]{2}{*}{$\begin{array}{c}\text { Forms of } \\
\text { ownership }\end{array}$} & \multicolumn{2}{|c|}{$2010 \mathrm{y}}$. & \multicolumn{2}{|c|}{2016 y. } & \multicolumn{2}{|c|}{2017 y. } \\
\hline & $\begin{array}{l}\text { thous. } \\
\text { People }\end{array}$ & Total,\% & $\begin{array}{l}\text { thous. } \\
\text { People }\end{array}$ & Total, \% & $\begin{array}{l}\text { thous. } \\
\text { People }\end{array}$ & Total, \% \\
\hline State & 2410,2 & 20,7 & 2330,4 & 17,5 & 2338,4 & 17,3 \\
\hline Non-state & 9218,2 & 79,3 & 10968,0 & 82,5 & 11182,0 & 82,7 \\
\hline Total & 11628,4 & 100,0 & 13298,4 & 100,0 & 13520,3 & 100,0 \\
\hline
\end{tabular}

Source: author's calculations based on statistical data of the state statistics committee of the republic of Uzbekistan

In 2017, the number of employed population increased by $16.3 \%$ in 2011 , including $13.7 \%$ in industry, $24.8 \%$ in construction and $18.2 \%$ in agriculture and forestry.

The share of those employed in the non-state sector increased from $79.3 \%$ in 2010 to $82.7 \%$ in 2017.

In order to ensure the employment of the population, it is desirable to strengthen the state policy in the labor market in the following areas:

- acceleration of development of small private enterprises and family business;

- Encouraging the micro-crediting system for these purposes; Maximum exploitation of opportunities for development of home-based labor forms in cooperation with large industrial enterprises and relatively small production enterprises;

- in the light and food industries, which intensify the development of the fertilizer industry, particularly in the use of agricultural and domestic raw materials and production of finished goods;

- address issues of expansion of non-agricultural employment in rural areas and to focus attention on the development of services sector;

- Activation of job placement services for the unemployed and social work.

As a result of the analysis of the main indicators of the current labor market (Table 4), it is possible to note that the employment rate in 2013 was above 109 percent, taking into account small businesses. The number of unemployed in the current year was almost the same as the number of registered unemployed. In the number of unemployed registered in recent years (2013-2017), the number of men has more than women, almost the same percentage (56\%). The employment rate fell to 78 percent in 2015 and amounted to 87 percent in 2016.

Table 4. The number of unemployed and the unemployment rate

\begin{tabular}{|c|c|c|c|c|c|c|}
\hline \multirow{2}{*}{ Years } & \multicolumn{2}{|c|}{ Number of unemployed (thousand people) } & \multicolumn{3}{c|}{ Unemployment rate\% } \\
\cline { 2 - 5 } & \multirow{2}{*}{ Total } & \multicolumn{2}{|c|}{ included } & \multirow{2}{*}{ Total } & \multicolumn{2}{c|}{ included } \\
\cline { 3 - 6 } & & men & women & & men & women \\
\hline 2014 & 687,0 & 301,5 & 385,5 & 5,1 & 4,9 & 5,2 \\
\hline 2015 & 709,4 & 311,2 & 398,2 & 5,2 & 5,0 & 5,3 \\
\hline 2016 & 724.0 & 317,5 & 406,5 & 5,8 & 5,6 & 6,0 \\
\hline 2017 & 837,0 & 367,1 & 469,9 & & 5,0 \\
\hline
\end{tabular}

Source: author's calculations based on statistical data of the state statistics committee of the republic of Uzbekistan

The study of the unemployment situation would be more appropriate when analyzing data on age groups, urban and rural areas.

The Government has taken certain measures to ensure employment of the able-bodied population in Uzbekistan. Specifically:
- Labor legislation is being improved; the employment and social protection centers are being intensified;

- employers, creating new jobs, are provided with tax, credit and other benefits;

- Measures are being taken to improve the labor force's competitiveness and competitiveness in the 


\begin{tabular}{|c|c|c|c|c|c|c|}
\hline \multirow{4}{*}{ Impact Factor: } & ISRA (India) & $=\mathbf{3 . 1 1 7}$ & SIS (USA) & $=0.912$ & ICV (Poland) & $=6.630$ \\
\hline & ISI (Dubai, UAE & $=0.829$ & РИНЦ (Russia & $=0.156$ & PIF (India) & $=1.940$ \\
\hline & GIF (Australia) & $=0.564$ & ESJI (KZ) & $=8.716$ & IBI (India) & $=4.260$ \\
\hline & JIF & $=1.500$ & SJIF (Morocco & $=5.667$ & OAJI (USA) & $=0.350$ \\
\hline
\end{tabular}

labor market. For this purpose system of vocational training and retraining of labor resources is further improved;

- Small businesses, private entrepreneurship, home-based, service and service sectors are being developed at a fast pace;

- socially vulnerable categories of the population have been financially supported and the procedure of job vacancies has been established;

- temporary and public works are organized at the expense of the state and local budgetary funds;

- focus on external and internal migration regulation.

It is well-known that the theory of statistics determines trends and prognostic indicators on the basis of which the dynamics of the pillars are extrapolated for the coming years.

For this purpose, the dynamics of 10 to 15 years of dynamics are constructed and the straight line $(\mathrm{Y}=$ $\mathrm{a}+\mathrm{b} * \mathrm{t})$, parabolic $(\mathrm{Y}=\mathrm{a}+\mathrm{b} * \mathrm{t}+\mathrm{c} * \mathrm{t} 2)$, hyperbolic $(\mathrm{Y}=\mathrm{a}+\mathrm{b} / \mathrm{t})$ or other types of equations. Various standard computer programs have been developed to determine which of the above equations can be conform to the characteristics of experimental data.

Below we present the technique for calculating the linear equation used to define the trend.

The linear equation, as outlined above, is expressed as follows:

$\mathrm{Y}=\mathrm{a}+\mathrm{b} * \mathrm{t}$

where "Y" is the indicator of the level of dynamics,

"A" - "free time", representing the influence of other factors influencing dynamics;
"B" - the regression coefficient, denoting the degree change in the degree of dynamics when the unit is transformed into one unit;

"T" - refers to the period (time) of the series of dynamics.

In the above equation, " $\mathrm{y}$ " and " $\mathrm{t}$ " are known, and "a" and "b" parameters are unknown. In order to determine the value of unknown elements, we first get the elements "a" and then " $b$ " and obtain the following equations system:

$$
\sum \mathrm{Y}^{*} \mathrm{t}=\mathrm{a} \sum \mathrm{t}+\mathrm{b} \sum \mathrm{t}^{2}
$$

In the above equation, "y" and " $t$ " are known, and "a" and "b" parameters are unknown. To determine the value of unknown elements, we first have to analyze the "a" and then "b" elements and obtain the following equation system:

$$
\sum \mathrm{Y}=\mathrm{n} * \mathrm{a}+\sum \mathrm{t}
$$

In this equation system, $\sum \mathrm{t}=0$ we consider the values of "a" and "b" as follows:

$\mathrm{a}=\sum \mathrm{Y} / \mathrm{n}$ ва $\mathrm{b}=\sum \mathrm{Y} * \mathrm{t} / \sum \mathrm{t}^{2}$

The above-mentioned theoretically considered approach is based on the data of the Republic of Uzbekistan for 2003-2017, on the basis of information on economically-employed and unemployed economically inexperienced population. Then, using special computer programs, it can be determined that the changes in the number of these parameters correspond to the function of the theory of the least squares.

The linear equation will have the following appearance according to the calculations: $Y_{t}=14$ $064,4+394,0 * \mathrm{t}$

Table 5. Labor Resources in Uzbekistan the trend in 2003-2017

\begin{tabular}{|c|c|c|c|c|c|}
\hline Years & $\begin{array}{c}\text { Number of } \\
\text { working } \\
\text { resources, } \\
\text { thousand } \\
\text { people, Y }\end{array}$ & $\mathbf{t}$ & $\mathbf{Y}^{* \mathbf{t}}$ & $\mathbf{t}^{\mathbf{2}}$ & $\mathbf{Y}_{\mathbf{t}}$ \\
\hline 1 & 2 & 3 & 4 & 5 & 6 \\
\hline 2003 & 13597,00 & -7 & $-95179,0$ & 49 & 11110,8 \\
\hline 2004 & 14048,80 & -6 & $-84292,8$ & 36 & 11874,2 \\
\hline 2005 & 14453,20 & -5 & $-72266,0$ & 25 & 12637,5 \\
\hline 2006 & 14816,50 & -4 & $-59266,0$ & 16 & 13400,9 \\
\hline 2007 & 15219,60 & -3 & $-45658,8$ & 9 & 14164,2 \\
\hline 2008 & 15685,70 & -2 & $-31371,4$ & 4 & 14927,6 \\
\hline 2009 & 16123,60 & -1 & $-16123,6$ & 1 & 15690,9 \\
\hline 2010 & 16726,00 & 0 & 0,0 & 0 & 16454,3 \\
\hline 2011 & 17286,40 & 1 & 17286,4 & 1 & 17217,7 \\
\hline 2012 & 17564,30 & 2 & 35128,6 & 4 & 17981,0 \\
\hline 2013 & 17814,1 & 3 & 53442,3 & 9 & 18744,4 \\
\hline 2014 & 18048,0 & 4 & 72192,0 & 16 & 19507,7 \\
\hline 2015 & 18276,1 & 5 & 91380,5 & 25 & 20271,1 \\
\hline 2016 & 18488,9 & 6 & 110933,4 & 36 & 21034,4 \\
\hline
\end{tabular}




\begin{tabular}{|c|c|c|c|c|c|c|}
\hline \multirow{4}{*}{ Impact Factor: } & ISRA (India) & $=\mathbf{3 . 1 1 7}$ & SIS (USA) & $=0.912$ & ICV (Poland) & $=6.630$ \\
\hline & ISI (Dubai, UAE & $=0.829$ & РИНЦ (Russia & $=0.156$ & PIF (India) & $=1.940$ \\
\hline & GIF (Australia) & $=0.564$ & ESJI (KZ) & $=8.716$ & IBI (India) & $=4.260$ \\
\hline & JIF & $=1.500$ & SJIF (Morocco & $=5.667$ & OAJI (USA) & $=0.350$ \\
\hline
\end{tabular}

\begin{tabular}{|l|c|c|c|c|c|}
\hline 2017 & 18666,3 & 7 & 130664,1 & 49 & 21797,8 \\
\hline Sum & $\mathbf{2 4 6} 814,5$ & $\mathbf{0 , 0}$ & $\mathbf{1 0 6} 869,7$ & $\mathbf{1 4 0}$ & $\mathbf{2 4 6 8 1 4 , 5}$ \\
\hline
\end{tabular}

Source: author's calculations based on statistical data of the state statistics committee of the republic of Uzbekistan

The sum of the paid labor resources on direct line function on column 6 of Table 5 is 246814.5 . The same sum was also obtained from experimental data. Hence, $\sum \mathrm{Y}=\sum \mathrm{Y}_{\mathrm{t}}$ is an equation that confirms the correct calculation.
The economic meaning of the regression coefficient determining the trend in the straight line equation " $b=763,4$ " indicates that the average annual increase in the number of workforce is 763.4 thousand people.

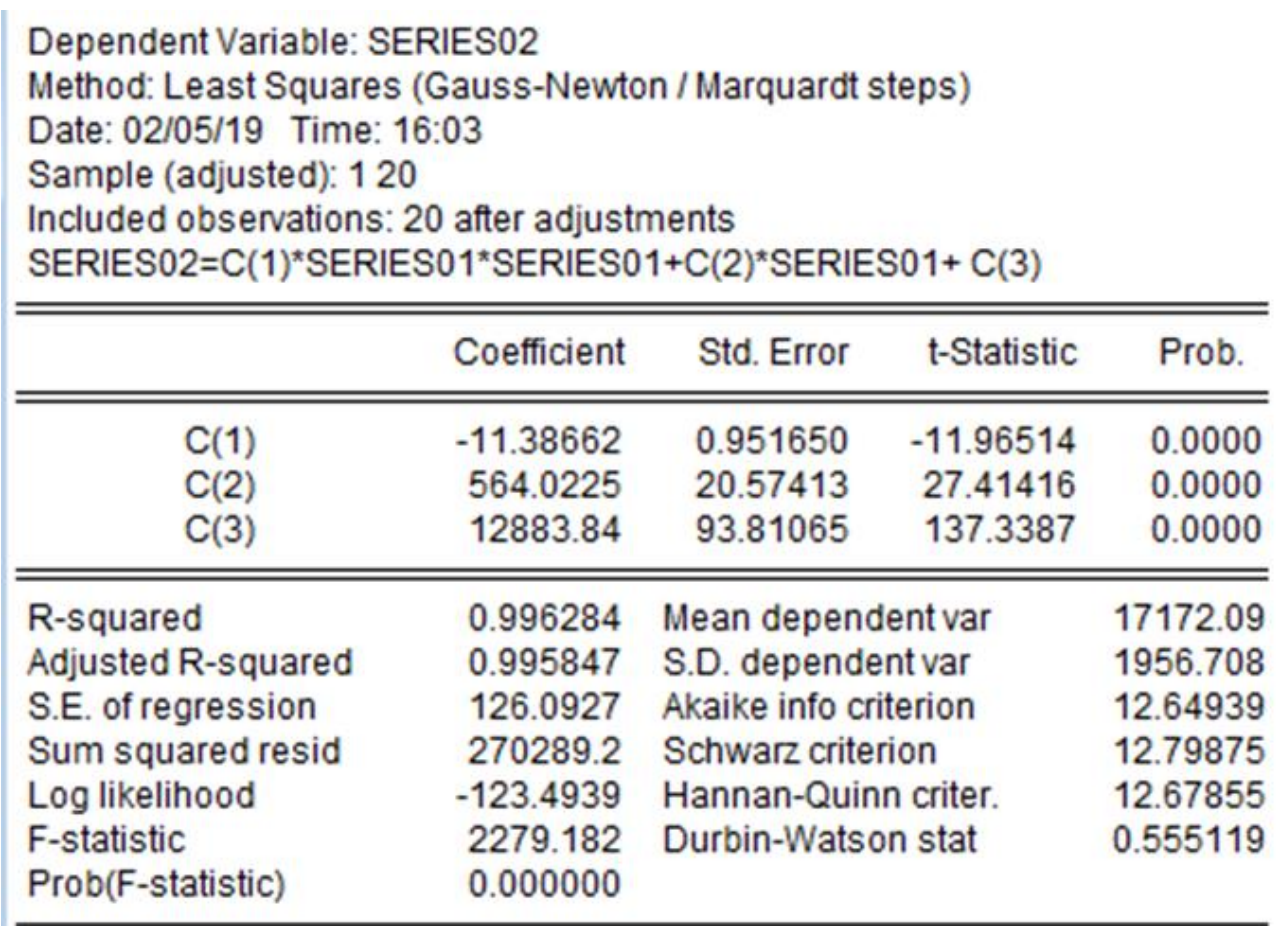

We use the variation coefficient to estimate the vibration level in our calculations: $\mathrm{B}=10.1$ percent. Thus, since this coefficient is less than 33 percent, we can acknowledge that the average amount that emerges as the relative homogeneity represents the real truth.

Using the equation of the equation, we can extrapolate the forecast of the workforce to 2022 .

Table 6. Number of labor force in Uzbekistan prognosis for the period up to 2022

\begin{tabular}{|c|c|}
\hline Years & $\begin{array}{c}\text { Forecast of labor resources, thousand } \\
\text { people }\end{array}$ \\
\hline 2018 & 19507,7 \\
\hline 2019 & 19889,4 \\
\hline 2020 & 20271,1 \\
\hline 2021 & 20652,8 \\
\hline 2022 & 21034,4 \\
\hline
\end{tabular}

Source: author's calculations based on statistical data of the state statistics committee of the republic of Uzbekistan

According to the prognosis estimates in Table 6, the number of workforce can reach 21.0 million passes by 2022 . 


\begin{tabular}{|c|c|c|c|c|c|c|}
\hline \multirow{4}{*}{ Impact Factor: } & ISRA (India) & $=\mathbf{3 . 1 1 7}$ & SIS (USA) & $=0.912$ & ICV (Poland) & $=6.630$ \\
\hline & ISI (Dubai, UAE & $=0.829$ & РИНЦ (Russia & $=0.156$ & PIF (India) & $=1.940$ \\
\hline & GIF (Australia) & $=0.564$ & ESJI (KZ) & $=8.716$ & IBI (India) & $=4.260$ \\
\hline & JIF & $=1.500$ & SJIF (Morocce & $=5.667$ & OAJI (USA) & $=0.350$ \\
\hline
\end{tabular}

Table 7. She is employed in the Republic of Uzbekistan the population growth forecast for 2003-2017 and the forecast for the period up to 2022

\begin{tabular}{|c|c|c|c|c|c|}
\hline Years & $\begin{array}{c}\text { Number of employed } \\
\text { in the economy, } \\
\text { thousand people } \\
\mathbf{Y}\end{array}$ & $\mathbf{t}$ & $\mathbf{Y} * \mathbf{t}$ & $\mathbf{t}^{\mathbf{2}}$ & $\mathbf{Y}_{\mathbf{t}}$ \\
\hline 1 & 2 & 3 & 4 & 5 & 6 \\
\hline 2003 & 9589,0 & -7 & $-67123,0$ & 49 & 9619,5 \\
\hline 2004 & 9910,6 & -6 & $-59463,6$ & 36 & 9904,8 \\
\hline 2005 & 10196,3 & -5 & $-50981,5$ & 25 & 10190,1 \\
\hline 2006 & 10467,0 & -4 & $-41868,0$ & 16 & 10475,5 \\
\hline 2007 & 10735,4 & -3 & $-32206,2$ & 9 & 10760,8 \\
\hline 2008 & 11035,4 & -2 & $-22070,8$ & 4 & 11046,1 \\
\hline 2009 & 11328,1 & -1 & $-11328,1$ & 1 & 11331,5 \\
\hline 2010 & 11628,4 & 0 & 0,0 & 0 & 11616,8 \\
\hline 2011 & 11919,1 & 1 & 11919,1 & 1 & 11902,1 \\
\hline 2012 & 12223,8 & 2 & 24447,6 & 4 & 12187,5 \\
\hline 2013 & 12523,3 & 3 & 37569,9 & 9 & 12472,8 \\
\hline 2014 & 12818,4 & 4 & 51273,6 & 16 & 12758,1 \\
\hline 2015 & 13058,3 & 5 & 65291,5 & 25 & 13043,4 \\
\hline 2016 & 13298,4 & 6 & 79790,4 & 36 & 13328,8 \\
\hline 2017 & 13520,3 & 7 & 94642,1 & 49 & 13614,1 \\
\hline 2018 & & 8 & & & 13899,4 \\
\hline 2019 & & 9 & & & 14184,8 \\
\hline 2020 & & 10 & & & 14470,1 \\
\hline 2021 & & 11 & & & 14755,4 \\
\hline 2022 & & 12 & & & 15040,8 \\
\hline
\end{tabular}

Source: author's calculations based on statistical data of the state statistics committee of the republic of Uzbekistan

Table 7 also provides $\sum \mathrm{Y}=\sum \mathrm{Y}_{\mathrm{t}}$, which means that the calculations are performed correctly. The coefficient of variation is 10.6 percent, and the average level of vibration can be considered as real.

By 2022, the estimated number of jobs in the economy is estimated at $\$ 15.0$ million. It is expected that the number of people employed in the economy will increase by 11.2 percent in 2022 compared to 2017 , or the number of employed people will be more than \$ 1.5 million. may increase. This can be done through large investments and public budget funds.

Table 8 shows that the unemployed part of the labor force (unemployed and economically inexperienced) is projected to increase from $5,152.2$ thousand in 2017 to $5,996,000$ in 2022 , or 16.4 percent. If the number of labor force forecasted for 2022 (21,034.4 thousand people) is higher then the share of the population in this category can increase from 27.6 percent in 2017 to 28.5 percent. The process of transition to market economy is becoming more and more urgent. In particular, $27.3 \%$ of the total number of employed population in the country (2017), ie more than 3 million people in the agricultural and forestry sector, have a large number of overpricing labor due to the optimization of farming businesses. 


\begin{tabular}{|c|c|c|c|c|c|c|}
\hline \multirow{4}{*}{ Impact Factor: } & ISRA (India) & $=3.117$ & SIS (USA) & $=0.912$ & ICV (Poland) & $=6.630$ \\
\hline & ISI (Dubai, UAE & $=0.829$ & РИНЦ (Russia & $=0.156$ & PIF (India) & $=1.940$ \\
\hline & GIF (Australia) & $=0.564$ & ESJI (KZ) & $=8.716$ & IBI (India) & $=4.260$ \\
\hline & JIF & $=1.500$ & SJIF (Morocco & $=5.667$ & OAJI (USA) & $=0.350$ \\
\hline
\end{tabular}

Table 8. Unemployed in the Republic of Uzbekistan dynamics and prognosis of economically inactive population

\begin{tabular}{|c|c|c|c|c|c|}
\hline Years & $\begin{array}{c}\text { The number of } \\
\text { unemployed and } \\
\text { economically inactive } \\
\text { persons, thousand } \\
\text { people, Y }\end{array}$ & $\mathbf{t}$ & $\mathbf{\mathbf { Y } ^ { * } \mathbf { t }}$ & $\mathbf{t}^{\mathbf{2}}$ & $\mathbf{Y}_{\mathbf{t}}$ \\
\hline 1 & 2 & 3 & 4 & 5 & 6 \\
\hline 2003 & 4008,0 & -7 & $-28056,0$ & 49 & 4162,4 \\
\hline 2004 & 4138,2 & -6 & $-24829,2$ & 36 & 4258,9 \\
\hline 2005 & 4256,9 & -5 & $-21284,5$ & 25 & 4355,4 \\
\hline 2006 & 4349,5 & -4 & $-17398,0$ & 16 & 4451,9 \\
\hline 2007 & 4484,2 & -3 & $-13452,6$ & 9 & 4548,4 \\
\hline 2008 & 4650,3 & -2 & $-9300,6$ & 4 & 4644,9 \\
\hline 2009 & 4795,5 & -1 & $-4795,5$ & 1 & 4741,4 \\
\hline 2010 & 5097,6 & 0 & 0,0 & 0 & 4837,9 \\
\hline 2011 & 5367,3 & 1 & 5367,3 & 1 & 4934,5 \\
\hline 2012 & 5340,5 & 2 & 10681,0 & 4 & 5031,0 \\
\hline 2013 & 5290,8 & 3 & 15872,4 & 9 & 5127,5 \\
\hline 2014 & 5229,6 & 4 & 20918,4 & 16 & 5224,0 \\
\hline 2015 & 5218,1 & 5 & 26090,5 & 25 & 5320,5 \\
\hline 2016 & 5190,5 & 6 & 31143,0 & 36 & 5417,0 \\
\hline 2017 & 5152,2 & 7 & 36065,4 & 49 & 5513,5 \\
\hline Sum & $\mathbf{7 2 5 6 9 , 2}$ & $\mathbf{0}$ & $\mathbf{2 7 0 2 1 , 6}$ & $\mathbf{2 8 0 , 0}$ & $\mathbf{7 2 5 6 9 , 2}$ \\
\hline 2018 & & 8 & & & 5610,0 \\
\hline 2019 & & 9 & & & 5706,5 \\
\hline 2020 & & 10 & & & 5803,0 \\
\hline 2021 & & 11 & & 5899,5 \\
\hline 2022 & & 12 & & 596,0 \\
\hline
\end{tabular}

Source: author's calculations based on statistical data of the state statistics committee of the republic of Uzbekistan

Thus, statistical forecasting and modeling of socio-economic situation such as unemployment, in turn, involves the study of links and dependability, change in space and time. The accuracy of estimation, analysis and forecasting will depend on the indicators and the correct selection of measurement methods. 


\begin{tabular}{|c|c|c|c|c|c|c|}
\hline \multirow{4}{*}{ Impact Factor: } & ISRA (India) & $=\mathbf{3 . 1 1 7}$ & SIS (USA) & $=0.912$ & ICV (Poland) & $=6.630$ \\
\hline & ISI (Dubai, UAE & $=0.829$ & РИНЦ (Russia & $=0.156$ & PIF (India) & $=1.940$ \\
\hline & GIF (Australia) & $=0.564$ & ESJI (KZ) & $=8.716$ & IBI (India) & $=4.260$ \\
\hline & JIF & $=1.500$ & SJIF (Morocco & $=5.667$ & OAJI (USA) & $=0.350$ \\
\hline
\end{tabular}

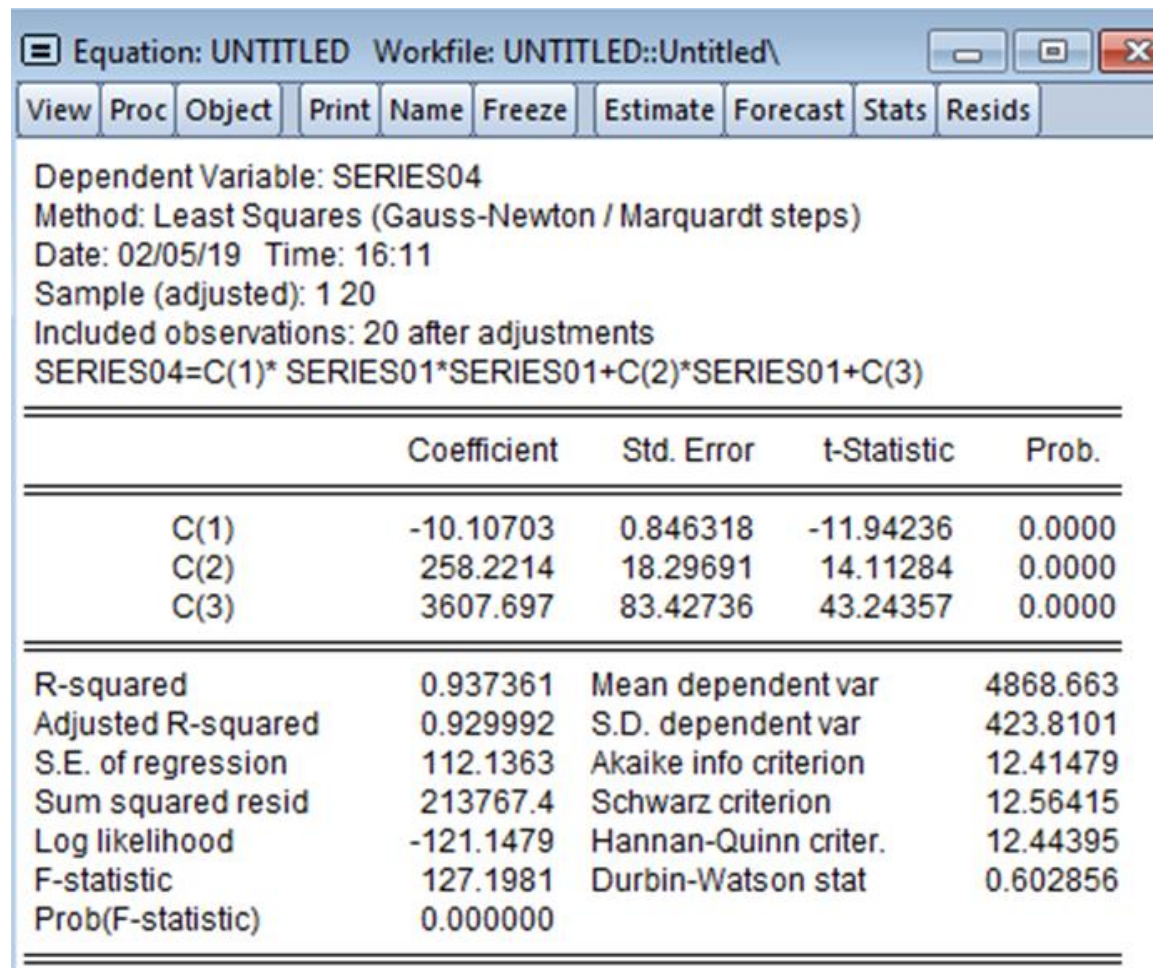

Prognostication of the situation in the labor market is the basis for the employment of the population as it allows to estimate the degree of fairness of the labor market:

1) the situation in which the demand and supply of the work force is being composed;

2) The likely number of non-employed people who can apply for employment assistance at the Employment Center;

3) Labor force composition, age, sex and place of residence;

4) the probable size of retraining and retirement of the unemployed;

5) the possible number of unemployed.

The labor market forecast is the basis for determining the amount of funds required for the employment program of the Employment Assistance Centers, as well as working out the priorities of the regional employment policy for the forecast period, and measures to prevent mass unemployment, and ensure social guarantees in the employment of citizens allowing you to

The development of the labor market forecast is based on the analysis of the socioeconomic situation and the impact of its impact on the situation in employment.

In the context of the staff redistribution and the labor market formation process, the importance of regular monitoring and evaluation of changes in employment, in particular demographic, social and economic conditions, increases significantly.

In this regard, the most important directions of the research are to evaluate the situation in the field of employment and to analyze the factors that determine it.

\section{Conclusions}

1. A hidden or unorganized labor market is much larger than the open market. This market is widely used in home, garden, garage construction, transportation, loading and unloading, harvesting and other seasonal and seasonal work. Such markets existed in Uzbekistan in the past. This employment can be considered a secondary employment, as some people may be employed on Saturdays, Sundays or in other leisure activities, while others may be considered basic because of low salaries. In the closed labor market, the rate of profitability and wages is considerably higher. Unfortunately, the information about the market, the number of participants, the rights to receive information in this market is not sufficiently high. In our opinion, it would be expedient to ask specific questions from observation questionnaires when speci fi cally statistical observation observations and future population lists are used to cover these issues.

4. The current hourly, monthly, monthly, quarterly and annual labor productivity, widely used in statistics of foreign countries, especially those of developed countries, is not published in statistical publications, which are calculated on the basis of some network statistics.

5. According to the results of correlationregression factor analysis, by 2022, the number of employed in the economy was 15.0 (data update), employment growth in industry and service industries, and the decline in the number of employed in 


\begin{tabular}{|c|c|c|c|c|c|c|}
\hline \multirow{4}{*}{ Impact Factor: } & ISRA (India) & $=3.117$ & SIS (USA) & $=0.912$ & ICV (Poland) & $=6.630$ \\
\hline & ISI (Dubai, UAE & $=0.829$ & РИНЦ (Russia) & $=0.156$ & PIF (India) & $=1.940$ \\
\hline & GIF (Australia) & $=0.564$ & ESJI (KZ) & $=8.716$ & IBI (India) & $=4.260$ \\
\hline & JIF & $=1.500$ & SJIF (Morocco & $=5.667$ & OAJI (USA) & $=0.350$ \\
\hline
\end{tabular}

agriculture positive system changes occur in the EU. There is also a significant change in income structure. According to it, the share of revenues from labor and entrepreneurial activity will increase and the share of social transfers will decrease.

6. It is expected that the differentiation in income of the population will be slightly reduced due to high rates of incomes of the poor, rational employment, development of private entrepreneurship and small business, and strengthening of social protection of the population.

7. Priority directions in employment and job market management should be primarily focused on the implementation of strategic goals. In our opinion, strategic tasks should include:
- Increasing the employment rate, first of all the rural population as well as the low level of employment of the population in the labor market;

- Improvement of network and territorial structure of employment;

- ensuring the harmonization of the demand and supply of labor force in terms of quantity and quality (professional) indicators in the labor market;

- improving the quality, skills and inter-regional mobility of the workforce.

8. On the basis of data from 2003-2017 on the number of labor force, economy and unemployment, projected indicators for these indicators up to 2022 were calculated as follows: labor resources in 2022 were 21.0 million people, those employed in the economy and 15.0 million soums.

\section{References:}

1. (1992). Resolution of the President of the Republic of Uzbekistan dated January 13, 1992 Law of the Republic of Uzbekistan "On Employment of the Population" No. 510-XII.

2. (1998). To declare invalid the Presidential decree of the Republic of Uzbekistan from 01.05.1998. Law of the Republic of Uzbekistan "On Employment of the Population" No. 616-I.

3. (n.d.). To declare invalid the Presidential decree of the Republic of Uzbekistan from January 21, PF-745 "On further deepening of economic reforms, protection of private property and entrepreneurship".

4. (2018). Resolution of the President of the Republic of Uzbekistan dated 14th of april 2018; Resolution of the Government of the Republic of Uzbekistan No. P-3856 "On measures to improve the efficiency and increase the efficiency of employment of the population".

5. (2018). The Decree of the President of the Republic of Uzbekistan from 08.06.2018 y. Decree of the President of the Republic of Uzbekistan "On the implementation of the" Every family-entrepreneur "program PQ-3777.

6. Keynes, J. M. (2007). The general theory of employment, interest and money. Favorites. (p.960). Moscow: Eksmo.

7. Lucas, R. E. (1981). Tobin and Monetarism: A Review Article. Journal of Economic Literature, №6, 562.

8. Ocwald, A. (1985). The Economic the ory of trade unions: an ntroductionary survey. Scandinavian Jornal of Economics, V. 67, $160-$ 193.
9. Rosen, H., \& Quandt, R. E. (1978). Estimating a diseguilibrium aggregate labour market. Reviem of Economicsand Statistics, V. 60, $371-379$.

10. Rudebush, C. D. (1986). Testing for Labour market disequilibrium with and exact excess demand disequilibrium model. Review of, Economics and Statistics, V. 68, 468-476.

11. Hayek, F. (1991). Unemployment and monetary policy. Government as a generator of the "business cycle". Economic Sciences, M., №1, p.91 - 95; №11. Pp. 57 - 66; №12. P. 39 - 48.

12. Zaslavskaya, T. I., \& Ryvkina, R. V. (1977). Methodological problems of the system study of the village. (p.315). Novosibirsk: Science.

13. Kostakov, V. G., \& Litvyakov, P. P. (1970). Labor Balance. (Content and methods of development). Ed. 2 - e add. and recycling. (p.287). Moscow: Economics.

14. Kotlyar, A. E., \& Trubin, V. V. (1978). Problems of regulation of the redistribution of labor. (p.168). Moscow: Economy.

15. Maslova, I. S. (1990). Effective employment and labor market. Bulletin of statistics, M., №12, 2322.

16. Nikifirova, A. A. (1991). Labor market: employment and unemployment. (p.184). Moscow: International Relations.

17. Strumylin, G. S. (1982). Problems of labor economics. (p.471). Moscow: Science.

18. Abdurahmonov, Q. X. (2009). Labor Economics. Textbook. (p.512). Tashkent: MEHNAT.

19. Alikariev, N. S. (1991). Management of human resources and employment in regional systems: Author's abstract. diss. Dr. Econ. sciences. 


\begin{tabular}{|c|c|c|c|c|c|c|}
\hline \multirow{4}{*}{ Impact Factor: } & ISRA (India) & $=\mathbf{3 . 1 1 7}$ & SIS (USA) & $=0.912$ & ICV (Poland) & $=6.630$ \\
\hline & ISI (Dubai, UAE & $=0.829$ & РИНЦ (Russia & $=0.156$ & PIF (India) & $=1.940$ \\
\hline & GIF (Australia) & $=0.564$ & ESJI (KZ) & $=8.716$ & IBI (India) & $=4.260$ \\
\hline & JIF & $=1.500$ & SJIF (Morocco & $=5.667$ & OAJI (USA) & $=0.350$ \\
\hline
\end{tabular}

(p.38). Tashkent: IC with the Scientific Center "Cybernetics".

20. Ubaydullaeva, R., Ata - Mirzaev, O., Umarova, N. (2006). Demographic processes in Uzbekistan and employment of the population. Scientific training manual. (p.96) Tashkent: University.

21. Holmuminov, S. R. (1998). Formation and development of the rural labor market (in Samarkand region). The dissertation of the doctoral dissertation on economic sciences. (p.46). Taskent.

22. Khuzhayev, N., Sattorov, N. (1993). Employment, modeling and the labor market. (p.192). Tashkent: Mexnat.

23. Shadiev, T. S. (1986). Economic models of agricultural development. (p.168). Tashkent: Fan.

24. Ibragimov, I. U., \& Tursunov, B. O. (2017). Enhancement the mechanism of analyzing of the methodological principles for the development and improvement of methods of assessment. Aydum, № 4, 11-13.

25. Tursunov, B. O. (2017). Osnovnye napravleniya podderzhki malogo biznesa $\mathrm{v}$ uzbekistane $\mathrm{i}$ zarubezhnyy opyt razvitiya predprinimatel"stva. Audit, № 6, 34-38.

26. Tursunov, B. O. (2017). perspektivy razvitiya tekstil"noy promyshlennosti v uzbekistane. Menedzhment $v$ Rossii $i$ za rubezhom, № 4, 7884.

27. Kasymov, S. S., Tursunov, B. O., \& Karimov, B. A. (2017). metody otsenki ekonomicheskoy nadezhnosti tekstil"nogo predpriyatiya $v$ usloviyakh rynochnoy ekonomiki. V sbornike: Teoriya i praktika organizatsii promyshlennogo proizvodstva. Effektivnost' organizatsii i upravleniya promyshlennymi predpriyatiyami: problemy i puti resheniya Materialy Mezhdunarodnoy nauchno-prakticheskoy konferentsii. (pp.139-144). Voronezhskiy gosudarstvennyy tekhnicheskiy universitet.

28. (n.d.). Retrieved 2019, from www.stat.uz 